\title{
Analysis of bacterial community structures in two sewage treatment plants with different sludge properties and treatment performance by nested PCR-DGGE method
}

\author{
LIU Xin-chun, ZHANG Yu, YANG Min*, WANG Zhen-yu, LV Wen-zhou \\ State Key Laboraton of Environmental Aquatic Chemistr; Research Center for Eco-Environmental Sciences, \\ Chinese Academy of Sciences, Beijing 100085, China. E-mail: liuxinchun415@yahoo.com.cn
}

Received 11 January 2006; revised 1 April 2006; accepted 12 April 2006

\begin{abstract}
The bacterial community structures in two sewage treatment plants with different processes and performance were investigated by denaturing gradient gel electrophoresis (DGGE) of nested polymerase chain reaction (nested PCR) amplified 16S rRNA gene fragments with group-specific primers. Samples of raw sewage and treated effiuents were amplified using the whole-cell PCR method, and the activated sludge samples were amplified using the extracted genomic DNA before the PCR products were loaded on the same DGGE gel for bacterial community analysis. Ammonia-oxidizing bacterial and actinomycetic community analysis were also carried out to investigate the relationship between specific population structures and system or sludge performance. The two plants demonstrated a similarity in bacterial community structures of raw sewage and activated sludge, but they had different effiuent populations. Many dominant bacterial populations of raw sewage did not appear in the activated sludge samples, suggesting that the dominant bacterial populations in raw sewage might not play an important role during wastewater treatment. Although the two plants had different sludge properties in terms of settleability and foam forming ability, they demonstrated similar actinomycetic community structures. For activated sludge with bad settling performance, the treated water presented a similar DGGE pattern with that of activated sludge, indicating the nonselective washout of bacteria from the system. The plant with better ammonium removal efficiency showed higher ammonia-oxidizing bacteria species richness. Analysis of sequencing results showed that the major populations in raw sewage were uncultured bacterium, while in activated siudge the predominant populations were beta proteobacteria.
\end{abstract}

Key words: activated sludge; wastewater treatment; sewage; community analysis; PCR-DGGE

\section{Introduction}

The activated sludge process, which uses activated sludge for the transformation of organic and inorganic pollutants, has contributed greatly to the improvement of the aquatic environment worldwide, and is still the most widely used process for the treatment of municipal wastewater because of its low operation cost and high performance. For more than 100 years endless efforts have been made by numerous researchers to improve this process, leading to the creation of many types of activated sludge technologies with more stable performance and new functions such as biological removal of phosphorus and nitrogen. In spite of these developments, however, many municipal treatment plants are still facing some troubles like sludge bulking, foaming, failures in nitrification or phosphate removal, etc. (Martins et al., 2004; Seviour et al., 1990). The reasons for these troubles might be very different, varying from improper design, to improper operation, exceptional influents, or some load shocks, etc.,

Project supported by the National Natural Science Foundation of China (No. 20510076, 50238050). *Corresponding author. E-mail: yangmin@rcees.ac.cn. but almost all of the troubles in function or performance are related to the changes of microbial community structures. Activated sludge, the core of a biological wastewater treatment system, generally contains many types of microorganisms, such as bacteria, protozoa, fungi, metazoan, viruses, and algae, while bacteria comprise approximately 95\% of the total microbial population (Jenkins et al., 1993) and play a key role in the purification of water quality. In spite of the importance of activated sludge for wastewater treatment, information on microbial ecology in biological wastewater treatment systems has been quite limited.

With the fast progress of molecular biological technologies in the last decade, some powerful tools, such as denaturing gradient gel electrophoresis of polymerase chain reaction (PCR-DGGE) and fluorescent in situ hybridization (FISH) etc., have been developed, and it is possible now to look into bacterial community structures without relying on time-consuming bias-bearing cultivation methods. Recently, a number of studies on ammoniaoxidizing bacteria (AOB) in wastewater treatment systems have suggested that different plants support different populations and levels of species richness. For instance a lab-scale biofilm reactor for treating domestic wastewater 
was dominated by $N$. europaea-like AOB (Okabe et al., 1999) while AOB populations from lab- and full scale plants in Germany were dominated by Nitrosospira-like bacteria or N. mobilis-like AOB respectively (Schramm $e t$ al., 1998; Juretschko et al., 1998). Nonetheless, based on the amoA approach, it is notable that Nitrosospira species are not important ammonia-oxidizing bacteria in full-scale wastewater treatment systems analyzed so far (Wagner and Loy, 2002). These new techniques might be very useful for system diagnosing or trouble shooting in the future. Although we have achieved a little in knowing the structures of activated sludge, we are far from understanding the microbial community structures in a biological wastewater treatment system. We want to know where they are from, why and how they change, and how they are related to the process performance.

Because of these concerns, changes of bacterial community structures were investigated by nested PCR-DGGE techniques with group-specific $16 \mathrm{~S}$ rRNA primers from raw sewage, to different sewage treatment units, and the treated effluents in two wastewater treatment plants of Beijing. Plant $\mathrm{A}$ adopts an anoxic-anaerobic-aerobic process $\left(\mathrm{A}_{2} \mathrm{O}\right)$ and another plant Plant $\mathrm{B}$ uses an anoxicaerobic process $(\mathrm{AO})$. The two plants have quite different sludge properties in the aspects of foam formation ability and settleability and have demonstrated different treatment performance, so the relationship between sludge properties, treatment performance and microbial community structures were also focused on.

\section{Materials and methods}

\subsection{Objective wastewater treatment plants}

The two plants are located in a northern suburb of Beijing and running stably during sampling period (March to August, 2004). Plant A, whose capacity of wastewater treatment is $200000 \mathrm{t} / \mathrm{d}$, with an $\mathrm{A}_{2} \mathrm{O}$ process and functions normally, with $92.7 \%$ BOD removal efficiency, 93.6\% $\mathrm{NH}_{4}{ }^{+}-\mathrm{N}$ removal efficiency and $97.1 \%$ phosphorus removal efficiency. It receives about $90 \%$ municipal wastewater and $10 \%$ industrial wastewater. The average sludge volume index (SVI) was $71 \mathrm{~L} / \mathrm{g}$.

Plant B, whose wastewater treatment capacity is 40000 $\mathrm{t} / \mathrm{d}$, uses an AO process, with $94.3 \%$ BOD removal efficiency, $66.7 \% \mathrm{NH}_{4}{ }^{+}-\mathrm{N}$ removal efficiency and $64.0 \%$ phosphorus removal efficiency. Slight foam formation was observed on the surface of the aeration tank. This plant receives $100 \%$ municipal wastewater. The average SVI was $197 \mathrm{~L} / \mathrm{g}$.

The recirculation ratios of activated sludge of Plant $A$ and Plant B were $65 \%$ and $100 \%$ respectively. The SRT, HRT and MLSS of Plant A and Plant B were $6 \mathrm{~d}$ and $10 \mathrm{~d}$, $15.8 \mathrm{~h}$ and $10 \mathrm{~h}, 1800 \mathrm{mg} / \mathrm{L}$ and $1000 \mathrm{mg} / \mathrm{L}$, respectively.

\subsection{Sample collection}

Fifty milliliters samples from the influent wastewater, mixed liquor of each unit, and supernatants of secondary settling tanks were collected from the two systems respectively in June, 2004. From Plant B, foam samples were also collected from the surface of an aeration tank. Samples were placed in sterile polypropylene tubes, taken to the lab within $1 \mathrm{~h}$ and stored at $-20^{\circ} \mathrm{C}$ before whole-cell PCR and DNA extraction $(<48 \mathrm{~h})$.

\subsection{Pretreatment of samples for whole-cell PCR}

The bacterial samples of the influents and effiuents were harvested by centrifugation of $1.5 \mathrm{ml}$ samples at $10000 \times \mathrm{g}$ for $30 \mathrm{~min}$. The cell pellets were washed once with phosphate-buffered saline $\left(93 \mathrm{mmol} \mathrm{Na}_{2} \mathrm{HPO}_{4}, 7\right.$ mmol $\mathrm{NaH}_{2} \mathrm{PO}_{4}$ ) before being re-suspended in $50 \mu \mathrm{l}$ of sterile distilled water, and then frozen at $-20^{\circ} \mathrm{C}$. The cell suspensions were subjected to three freeze-thaw cycles and then used for whole-cell PCR amplification (Òvreas et al., 1997).

\subsection{DNA extraction}

Bacteria DNA was extracted from 50-100 mg (wet weight) samples described as Miller et al. (1999) with a small modification at the initial step: $1 \mathrm{ml}$ phosphate buffer salt solution (100 mmol/L $\mathrm{NaH}_{2} \mathrm{PO}_{4}, \mathrm{pH} \mathrm{8.0)}$ was added to and mixed with the sample, and then the tube was sonicated for $30 \mathrm{~s}$ on ice. The product from DNA extraction was verified by electrophoresis in $0.8 \%$ agarose (Promega, USA).

\subsection{PCR and DGGE}

All the used primers and PCR conditions are listed in Table 1. The final concentrations of different components in the mastermix were: $15 \mathrm{pmol}$ of each primer, $200 \mu \mathrm{mol}$ of each deoxynucleoside triphosphate, $10 \times$ reaction buffer, $1.25 \mathrm{U} / 50 \mu \mathrm{l}$ of Taq DNA Polymerase (Promega, USA),

Table 1 PCR primers used in this study

\begin{tabular}{|c|c|c|c|c|c|c|c|c|c|}
\hline \multirow{3}{*}{ Target } & \multirow{3}{*}{ Primers } & \multirow{3}{*}{$\begin{array}{l}\text { Number } \\
\text { of cycles }\end{array}$} & \multicolumn{6}{|c|}{ PCR conditions } & \multirow{3}{*}{ References } \\
\hline & & & \multicolumn{2}{|c|}{ Denaturation } & \multicolumn{2}{|c|}{ Annealing } & \multicolumn{2}{|c|}{ Elongation } & \\
\hline & & & $\begin{array}{l}\text { Temp. } \\
\left({ }^{\circ} \mathrm{C}\right)\end{array}$ & $\begin{array}{l}\text { Time } \\
\text { (min) }\end{array}$ & $\begin{array}{l}\text { Temp. } \\
\left({ }^{\circ} \mathrm{C}\right)\end{array}$ & $\begin{array}{l}\text { Time } \\
(\mathrm{min})\end{array}$ & $\begin{array}{l}\text { Temp. } \\
\left({ }^{\circ} \mathrm{C}\right)\end{array}$ & $\begin{array}{l}\text { Time } \\
(\mathrm{min})\end{array}$ & \\
\hline First round & & 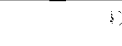 & & & & & & & \\
\hline Actinomycetes & F243, R1378r & 30 & 95 & 1 & 63 & 1 & 72 & 2 & Heuer et al., 1997 \\
\hline Ammonia oxidizers & $\begin{array}{l}\text { CTO189fAB, } \\
\text { CTO189fC, } \\
\text { CTO654r }\end{array}$ & 30 & 95 & 1 & 57 & 1 & 72 & 1 & Kowalchuk et al., 1998 \\
\hline \multicolumn{10}{|l|}{ Second round } \\
\hline Bacteria & $\begin{array}{l}\text { GC-P338f, } \\
\text { P518r }\end{array}$ & 30 & 95 & 1 & 55 & 1 & 72 & 1 & Òvreas et al., 1997 \\
\hline
\end{tabular}


$400 \mathrm{ng} / \mu \mathrm{l}$ of bovine serum albumin, and DNase and RNase free filter sterilized water.

For bacteria population analysis of raw sewage, treated water and activated sludge samples, the bacterial general primers GC-P338f and P518r were used to directly amplify above samples by adding $2 \mu$ of extracted DNA or $2 \mu$ of pretreated cell suspensions to $48 \mu \mathrm{l}$ PCR mastermix.

For AOB and actinomycetic population analysis of activated sludge samples, a nested PCR technique was used to increase the sensitivity. In the first round, $1 \mu$ l of extracted DNA was added to $24 \mu$ l of PCR mastermix and different group-specific primers were used, each with their own corresponding PCR protocol. During the second PCR round, $1 \mu \mathrm{l}$ of amplified product from the first round was added to $49 \mu$ l of the PCR mixture and then reamplified by using the bacterial primers GC-P338f and P518r in the same PCR protocol (Table 1). Because actinomycetes, $A O B$ groups belong to the domain of bacteria, the bacterial primers P338f and P518r used in the second PCR round should reamplify all fragments obtained after the first PCR round (Boon et al., 2002).

After PCR amplification, $3 \mu$ l of the PCR product was electrophoresed on $1.2 \%(\mathrm{w} / \mathrm{v})$ agarose gel, and then checked with ethidium bromide staining.

Before each run of cycles, the temperature was held at $95^{\circ} \mathrm{C}$ for $5 \mathrm{~min}$ and after each run the temperature was kept at $72^{\circ} \mathrm{C}$ for $10 \mathrm{~min}$ for final template elongation.

DGGE was performed with the Dcode System (USA, Bio-Rad Co.). PCR products were loaded onto $10 \%$ $(\mathrm{w} / \mathrm{v})$ polyacrylamide gel in $1 \times \mathrm{TAE}$ buffer $(20 \mathrm{mmol} / \mathrm{L}$ Tris, $10 \mathrm{mmol} / \mathrm{L}$ acetate, $0.5 \mathrm{mmol} / \mathrm{L}$ EDTA $(\mathrm{pH}$ 7.4)). The $10 \%(w / v)$ polyacrylamide gel (bisacrylamide : acrylamide $=37.5: 1$ ) were made with denaturing gradients ranging from $30 \%$ to $50 \%$ (where $100 \%$ denaturant contains $7 \mathrm{~mol} / \mathrm{L}$ urea and $40 \%$ formamide). The electrophoresis was run at $60^{\circ} \mathrm{C}$, first for $30 \mathrm{~min}$ at 25 $\mathrm{V}$ and subsequently for $16 \mathrm{~h}$ at $80 \mathrm{~V}$. After electrophoresis, the gels were stained for $15 \mathrm{~min}$ with ethidium bromide and photographed on a UV transillumination table with a Gel Documentation Systems (BIO-RAD LaboratoriesSegrate, Milan, Italy).

\subsection{Analysis of DGGE patterns}

The processing of the DGGE gel was done with the BIORAD software Quantity One 4.3.0. DGGE fingerprints were automatically scored by the presence or absence of co-migrating bands, independent of intensity. Pairwise community similarities were quantified using the Dice index $\left(C_{s}\right)$ as: $C_{5}=2 j /(a+b)$, where $j$ is the number of bands common to samples $\mathrm{A}$ and $\mathrm{B}$, and $a$ and $b$ are the number of bands in samples A and B, respectively (Dice, 1945). This index ranges from 0 (no common bands) to 1 (identical band patterns). Dendrograms were constructed using the complete linkage method with arithmetic averages (UPGMA) (Sokal and Michener, 1958). Binary sequences were generated for individual DGGE lanes by determining the number and position of bands compared to the total number of band positions detected.
1.7 Recovery of bands from DGGE gels and sequence analysis

Bands chosen for sequence analysis were carefully excised from the DGGE gel with a sterile scalpel. For each band selected, only the middle portion of each band was excised. Then the slices were placed in $2-\mathrm{ml}$ sterilized screw-cap polypropylene tubes and $60 \mu \mathrm{l} \mathrm{TE}$ buffer was added. The DNA was allowed to passively diffuse into water at $4^{\circ} \mathrm{C}$ overnight. $5 \mu \mathrm{l}$ of the eluate was used as template DNA for a PCR performed with the primers and conditions described above for environmental samples. 5 $\mu l$ of each PCR product was subjected to agarose gel electrophoresis to check product recovery and to estimate product concentration. $5 \mu \mathrm{l}$ of each reaction mixture was also subjected to DGGE analysis to confirm the melting behavior of the band recovered. The remaining PCR products $(40 \mu 1)$ were sent to Shanghai Genecore Biotechnology Company for sequence analysis.

\section{Results and discussion}

\subsection{DGGE patterns of sewage, activated sludge and effluent samples}

Bacterial community structures in raw sewage, aeration tanks, and the treated effluent of the two plants were investigated by PCR-DGGE method, and the results are shown in Fig.1. Dice coefficients on the DGGE patterns of Fig.1 were calculated using Quantity One 4.3.0, and a cluster analysis based on the values of Dice coefficients was performed using the Pearson correlation (1926) and visualized in a dendrogram (Fig.2).

It can be seen that raw sewage samples of the two plants were located in one cluster due to their similarity (Dice coefficient, 73\%), which maybe result from their similar sewage constituents (mainly municipal wastewater). The similar sewage constituents might also lead to the similarity of activated sludge samples of the two plants (Dice coefficient, 60\%). However, the Dice coefficients of raw sewage and activated sludge in both plants were very low: $27 \%$ and $29 \%$ respectively, indicating that the dominant species in sewage might not play an important role in wastewater treatment. This result is different from that of Curtis and Craine (1998), in which study the plants received varying amounts of domestic and industrial waste.

The microbial community structures in raw sewage have seldom been investigated because many attentions have to be focused on activated sludge. Bacteria in raw sewage are considered to derive from two general sources: sanitary wastes and the soil. Most bacterial populations contained in sanitary wastes are intestinal microorganisms which mainly result from excretion of human or animal hosts. Previous study showed that many enteric bacterial populations are known to decline in receiving waters (Hood and Ness, 1982). Therefore, some bacteria populations like the enteric microorganisms would become difficult to be detected in aeration tanks due to their poor survival rate in nonhost environments (Marshall 1980; Rozen and Belkin, 2001). 


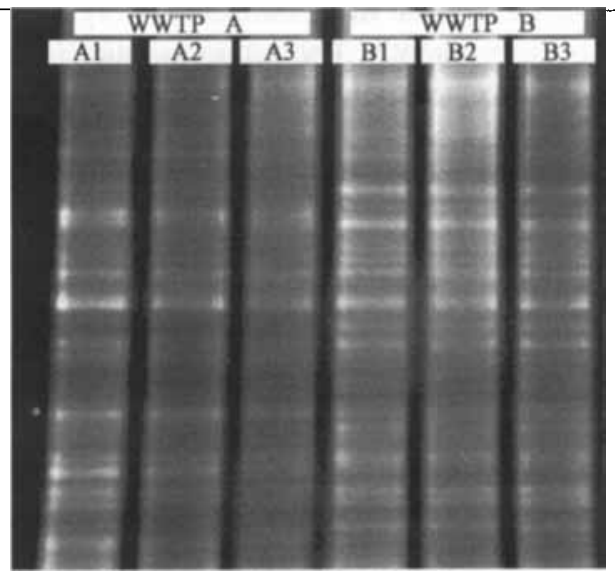

Fig. 1 DGGE patterns of samples taken from sewage, activated sludge and effluents. Lane 1: raw sewage of Plant A; Lane 2: activated sludge of Plant A; Lane 3: the effluent of Plant A; Lane 4: raw sewage of Plant B; Lane 5: activated sludge of Plant B; Lane 6: the effluent of Plant B. Numbers 1-25 indicate the excised bands from which sequences were determined.

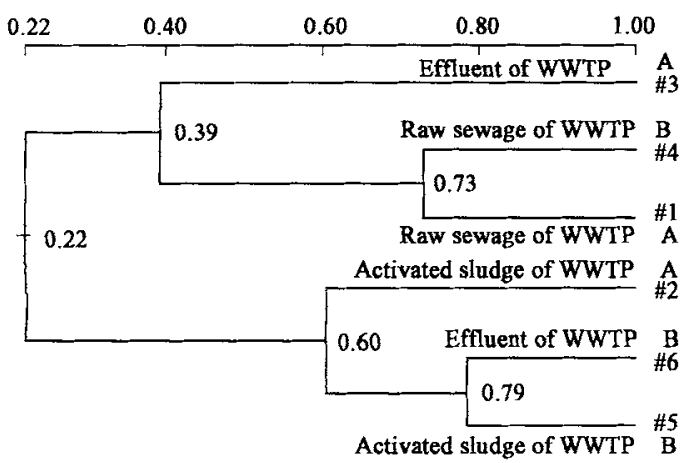

Fig. 2 Cluster analysis of the DGGE profile in Fig. 1 using the complete linkage method. WWTP: waste water treatment plant.

Soil microorganisms, such as actinomycetes and AOB etc., have different behaviors in receiving waters. Actinomycetes are the most abundant group of bacteria in soils (90\%) and show primary biodegradative activity (Kieser et al., 2000). They are active in the decomposition of organic materials in soil, and can degrade agricultural and urban wastes (McCarthy, 1987). When flushed into wastewater, most soil bacteria would become inactivated on account of the decrease of oxygen levels. But some of them, like $A O B$, will become competitive again when they enter the aeration tank because there is a sufficient supply of oxygen (Kowalchuk et al., 1998). So, it is reasonable that bacterial community structures in raw sewage and in activated sludge are different.

Although the two plants had similar bacterial community structures in activated sludge, the bacterial populations of their effluents were different (Dice coefficient, 25\%). The difference in settleability between the two systems might be the main reason for the difference of bacterial community structures. The SVI of Plant B was $197 \mathrm{~L} / \mathrm{g}$, which was higher than that of Plant A $(71 \mathrm{~L} / \mathrm{g})$. The bad settleability of activated sludge in Plant B possibly led to the washing out of bacteria without selectivity, which is why the similarity of bacterial community structures between the effluent and activated sludge was so high (Dice coefficient, 79\%). This phenomenon maybe results from the short anoxic compartment of Plant $B$, which is only $10 \mathrm{~m}$ long and has high dissolved oxygen level (1.2-1.8 $\mathrm{mg} / \mathrm{L}$ ). This condition is favorable for growth of many aerobic filamentous bacteria, which usually cause high SVI in aeration tanks. On the other hand, only a small species of bacteria were selectively washed out from Plant $A$, resulting in the low similarity of bacterial community structures between the effluent and activated sludge (Dice coefficient, 26\%).

\subsection{Bacterial population shifts in different treatment compartments}

Fig. 3 shows the DGGE patterns of sludge samples taken from different compartments of the two plants. The bacterial community structures among compartments in each system were similar and no obvious bacteria shifts were observed. In order to find out if there are dominant foaming bacteria existing in the foam of Plant B, DGGE analysis of the foam sample was performed using bacteria general primers. It is interesting that the bacterial populations of the foam were almost identical with that of activated sludge. This result indicates that the bacteria which caused slighter foaming in the aeration tank did not represent the dominant metabolic bacterial group in Plant B and could not be determined by common PCR method.

In order to increase the sensitivity, a nested PCR approach was chosen to facilitate the analysis of the $16 \mathrm{~S}$ rRNA gene fragments of different bacterial subgroups by DGGE. A comparable approach has been used earlier by Heuer et al. (1997) to monitor actinomycete community changes in potato rhizosphere and to investigate actinomycete diversity in different soils. Phillips et al. (2000) detected AOB by using a nested PCR approach with the specific primers, while the abundance of these ammonium oxidizers was maximum $0.01 \%$ of the total bacterial soil community. The advantage of using nested PCR with specific primers is the increased sensitivity, which makes it possible to visualize also those species that are present in lower numbers.

The use of nested PCR should be evaluated with cau-

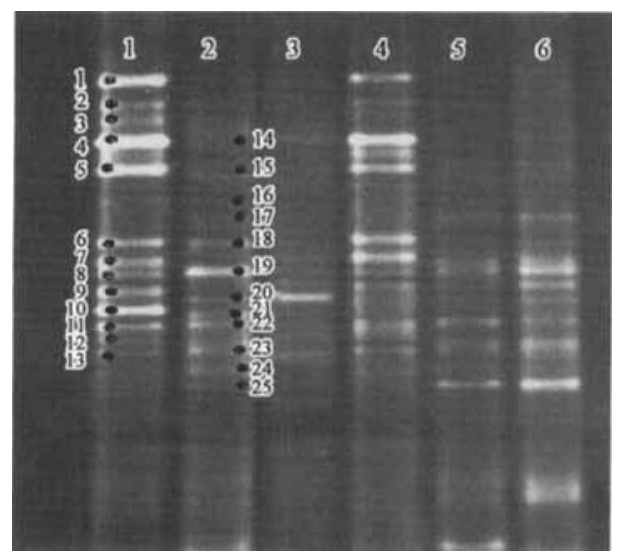

Fig. 3 DGGE patterns of samples from different compartments of Plant $A$ and Plant B. A1: anoxic reactor of Plant A; A2: anaerobic reactor of Plant A; A3: aerobic reactor of Plant A; B1: anoxic reactor of Plant B; $B 2$ : aerobic reactor of Plant $B, B 3$ : sludge foam from the aerobic reactor of Plant $B$. 


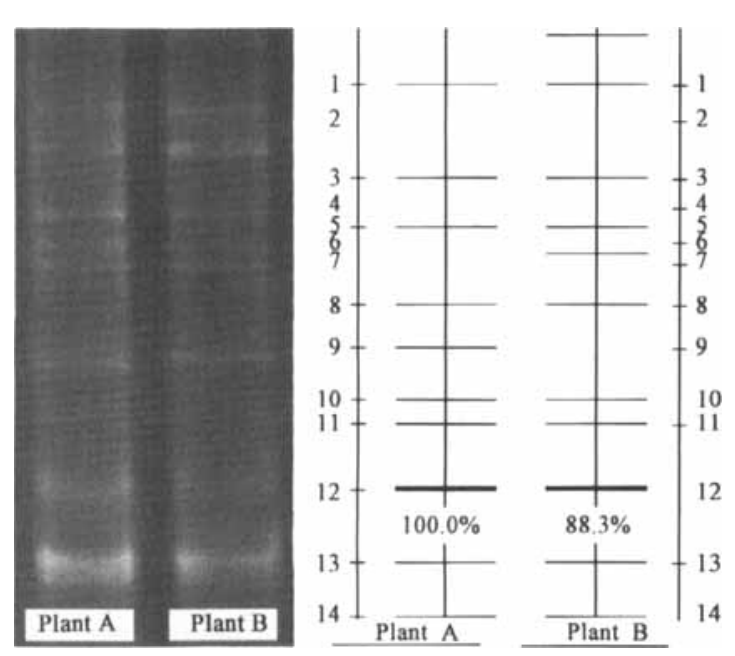

Fig. 4 Comparison of actinomycetic communities between the two plants. The left side shows the DGGE patterns of activated sludge samples taken from aeration tanks of Plant A and B, respectively; the right part gives the analysis results of lane comparison from the DGGE patterns using Quantity One 4.3.0 software.

tion. A possible disadvantage of applying two successive PCR reactions is the introduction of an even greater bias due to preferential amplification (Suzuki and Giovannoni, 1996). However, according to previous studies this bias of preferential amplification may be overestimated, and the intensity of the $16 \mathrm{~S}$ rDNA bands in a DGGE gel may correspond at least semiquantitatively with the abundance of the corresponding species (Heuer et al., 1997).

Because the two plants demonstrated different activated sludge properties and $\mathrm{NH}_{4}{ }^{+}-\mathrm{N}$ removal efficiencies, in order to look for the relationships of bacterial communities and activated sludge properties or treatment performance, actinomycetes and $\mathrm{AOB}$ community structure analysis were then carried out by nested PCR-DGGE with groupspecific primers.

\subsection{Actinomycetic community analysis of activated sludge samples in the two systems}

Because the higher SVI of activated sludge is usually related to the various types of filamentous organisms, actinomycetes and the main filamentous organisms were focused on subsequently. The actinomycetic communities of the two plants were compared and the results are shown in Fig.4. The major bands were exercised from the two lanes and sent for sequencing. The sequencing results have been deposited in GenBank as DQ105633 to DQ105638. It is interesting that Plant $\mathrm{A}$, which did not demonstrate any sludge bulking phenomenon, had a similar actinomycetic community structure with Plant B. The Dice coefficient for the actinomycetic communities of the two plants was as high as $88.3 \%$, suggesting that the actinomycetic populations in Plant B might have no obvious relationship with its slighter bulking phenomenon. It is reported that more than 25 different filament "types" in activated sludge could cause bulking questions (Liao et al., 2004). Levantesi et al. (2004) had found that filamentous $\alpha$-proteobacteria also associated with bulking in industrial wastewater treatment plants. Therefore, apart from actinomycetes, other microorganisms maybe also could bring about high SVI in Plant B. Furthermore, Martins et al. (2004) thought that bulking sludge can be approached as a microbiological problem (occurrence of a specific filamentous bacterium) or as an engineering problem (growth of bacteria with a filamentous morphology). So, further studies are necessary to draw a conclusion regarding the main reason for the high SVI of Plant B.

\subsection{Ammonia-oxidizing bacteria (AOB) community structures in the two systems}

The AOB community structures in the two systems were compared, and the results are shown in Fig.5. According to the automatic counting results of the Quantity One 4.3.0 software, Plant A had more band number than Plant B. Moreover, the two systems had different AOB community structures. The higher ammonium removal effect in Plant A might be attributed to its higher $A O B$ species richness to some extent.

The main bands were also exercised from the DGGE gel and sent for sequencing. The sequences reported in this study are available in GenBank under accession No. DQ181630, DQ196207 to DQ196214. Sequence analysis of $16 \mathrm{~S}$ rRNA genes reveals that all bands were closely related to Nitrosomonas spp. This conclusion is in line with the study by Limpiyakorn et al. (2005), who found that most of the DGGE bands of various sewage treatment plants in Tokyo were closely related to Nitrosomonas spp., not to Nitrosospira spp. by BLAST analysis.

\subsection{Results of bacterial community sequencing}

To obtain insight into the identities of major bacterial populations, discernable DGGE bands in raw sewage and activated sludge samples (Fig.2) were all excised and used for nucleotide sequence analysis. The partial sequences of 16S rRNA genes obtained in this study were submitted to the GenBank under accession numbers: DQ105639
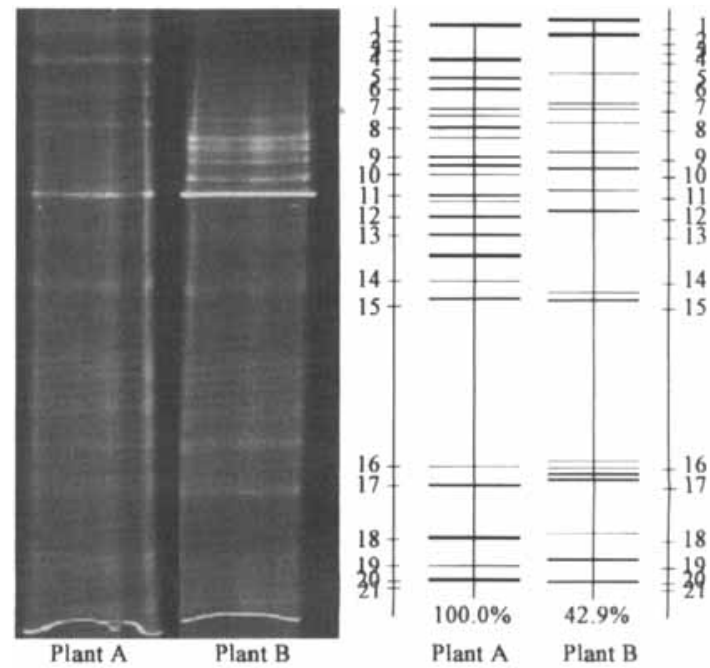

Fig. 5 Comparison of AOB communities between the two systems. The left side shows the DGGE pattems of activated sludge samples taken from aeration tanks of Plant $A$ and Plant $B$, respectively. The right side gives the analysis results of lane comparison from the DGGE patterns using Quantity One 4.3.0 software. 
to DQ105643; DQ181629 to DQ181632; AY338406 to AY338412.

Among the total of 13 bands recovered from the raw sewage sample of Plant $\mathrm{A}$, band 3 and band 8 did not have good sequencing results, indicating that they may contain duplicate DNA sequences (Ferris et al., 1996). Band 12 only produced an uncertain nucleotide sequence, indicating that it might be a chimeric sequence. Most bands detected from raw water were uncultured bacteria, while others were proteobacteria.

Most sequences recovered from activated sludge showed good match with sequences present in public databases. By comparing sequencing results, it was found that five activated sludge bands were identical to five sewage bands. Among the total of 12 bands, there were six bands belonging to beta proteobacteria, two bands belonging to gamma proteobacteria and others belonging to uncultured bacteria. Bacteria from the beta proteobacteria subclass have recently been observed by FISH to be dominant in activated sludge communities (Manz et al., 1994; Wagner et al., 1993). Given their numerical dominance, it is likely that representatives of the beta subclass play roles in aspects of activated sludge, such as degradation of organic material, removal of nutrients, and formation of floc structure.

Bacteria of the gamma proteobacteria, such as Acinetobacter species, have been considered to be related to phosphate removal (Kavanaugh and Randall, 1994). But culture-independent methods such as FISH found that Acinetobacter spp. were present in small proportions in activated sludge (ca. 3\% to 6\%) and the role of Acinetobacter spp. in activated sludge processes had been overrated (Wagner et al., 1994). DGGE patterns of this study showed that the gamma proteobacteria appeared simultaneously in the two plants, but came along with different phosphate removal performances. This phenomenon indicates that the gamma proteobacteria had involved in the process of phosphate removal, but might not play a crucial role.

The analysis of microbial community structures in this study was based on the PCR-DGGE technique, which is a fast and convenient tool in tracking bacterial community changes and comparing different biological treatment systems. This method, however, can not provide accurate quantification information, and the target bacteria could only be determined at the genus level because only limited rDNA sequence lengths can be excised from DGGE gels. The combination of this method with some quantitative techniques (such as real time PCR, Clone or FISH, etc.) could provide a better understanding of microbial community structures in wastewater treatment processes.

\section{Conclusions}

PCR-DGGE analysis and band comparison demonstrated that many dominant populations in raw sewage did not play an important role in the process of wastewater treatment. The bacterial community structures of the two systems were quite similar although they use different processes, and although they demonstrated different treatment and sludge performance. The system with better ammonium removal performance showed a higher AOB species richness. However, the plant associated with sludge foaming had a high similarity in terms of actinomycetic community structure to that without sludge foaming. For activated sludge with good settling performance, the DGGE pattern of the treated water would present quite a few dominant bacteria species.

Analysis of sequencing results showed that the major populations in raw sewage were uncultured bacterium, while in activated sludge the predominant populations were beta proteobacteria.

Acknowledgements: The authors appreciate the assistance provided by Beijing Drainage Group Co., Ltd. in the sampling work.

\section{References}

Boon N, Windt W D, Verstraete W et al., 2002. Evaluation of nested PCR-DGGE (denaturing gradient gel electrophoresis) with group-specific 16S rRNA primers for the analysis of bacterial communities from different wastewater treatment plants[J]. FEMS Microbiol Ecol, 39: 101-112.

Curtis T P, Craine N G, 1998. The comparison of the diversity of activated sludge plants[J]. Wat Sci Tech, 37: 71-78.

Dice L R, 1945. Measures of the amount of ecological association between species[J]. Ecology, 26: 297--302.

Ferris M J, Muyzer G, Ward D M, 1996. Denaturing gradient gel electrophoresis profiles of $16 \mathrm{~S}$ rRNA-defined populations inhabiting a hot spring microbial mat community[J]. Appl Environ Microbiol, 62: 340-346.

Heuer H, Krsek M, Baker P et al., 1997. Analysis of actinomycete communities by specific amplification of genes encoding 16S rRNA and gel-electrophoretic separation in denaturing gradients[J]. Appl Environ Microbiol, 63: 3233-3241.

Heuer H, Smalla K, 1997. Application of denaturing gradient gel electrophoresis (DGGE) and temperature gradient gel electrophoresis (TGGE) for studying soil microbial communities[M]. In: Modern soil mmicrobiology (van Elsas J. D., Wellington E. M. H., Trevors J. T., ed.). New York: Marcel Dekker.

Hood M A, Ness G E, 1982. Survival of Vibrio cholerae and Escherichia coli in estuarine waters and sediments[J]. Appl Environ Microbiol, 43: 578-584.

Jenkins D, Richard M G, Daigger G T, 1993. Manual on the causes and control of activated sludge bulking and foaming[M]. 2nd ed. Michigan: Lewis Publishers.

Juretschko S, Timmermann G, Schmid M et al., 1998. Combined molecular analyses of nitrifying bacterium diversity in activated sludge: Nitrosococcus mobilis and Nitrospiralike bacteria as dominant populations[J]. Appl Environ Microbiol, 64: 3042-3051.

Kavanaugh R G, Randall C W, 1994. Bacterial populations in a biological nutrient removal plant[J]. Water Sci Technol, 29(7): $25-34$

Kieser T, Bibb M J, Buttner M J et al., 2000. Preparation and analysis of genomic and plasmid DNA[M]. In: Practical streptomyces genetics (Kieser T., Bibb M. J., Buttner M. J., et al., ed.). England: The John Innes Foundation, Norwich. 161-210.

Kowaichuk G A, Bodelier P L E, Heilig G H J et al., 1998. Community analysis of ammonia-oxidizing bacteria, in relation to oxygen availability in soils and root-oxygenated sediments, using PCR, DGGE and oligonucleotide probe 
hybridization[J]. FEMS Microbiol Ecol, 27: 339-350.

Levantesi C, Beimfohr C, Geurkink B et al., 2004. Filamentous alphaproteobacteria associated with bulking in industrial wastewater treatment plants[J]. Syst Appl Microbiol, 27: $716-727$.

Liao J, Lou I, de los Reyes III F L, 2004. Relationship of speciesspecific filament levels to filamentous bulking in activated sludge[J]. Appl Environ Microbiol, 70: 2420-2428.

Limpiyakorn T, Shinohara Y, Kurisu F et al., 2005. Communities of ammonia-oxidizing bacteria in activated sludge of various sewage treatment plants in Tokyo[J]. FEMS Microbiol Ecol, 54: 205-217.

Manz W, Wagner M, Amann R et al., 1994. In situ characterization of the microbial consortia active in two wastewater treatment plants[J]. Water Res, 28: 1715-1723.

Martins A M P, Pagilla K, Heijnen J J et al., 2004. Filamentous bulking sludge-a critical review[J]. Water Res, 38: 793817.

Marshall K C, 1980. Adsorption of microorganisms to soils and sediments[M]. In: Adsorption of microorganisms to surfaces (Britton G., Marshall K. C., ed.). New York, N.Y: Wiley. 317-329.

McCarthy A J, 1987. Lignocellulose-degrading actinomycetes[J]. FEMS Microbiol Rev, 46: 145-163.

Miller N, Bryant J E, Madsen E L et al., 1999. Evaluation and optimization of DNA extraction and purification procedures for soil and sediment samples[J]. Appl Envir Microbiol, 65: $4715-4724$.

Okabe S, Satoh H, WatanabeY, 1999. In situ analysis of nitrifying biofilms as determined by in situ hybridisation and the use of microelectrodes[J]. Appl Environ Microbiol, 65: 31823191.

Òvreas L, Forney L, Daae FL et al., 1997. Distribution of bacterioplankton in meromictic lake Saelevannet, as determined by denaturing gradient gel electrophoresis of PCR-amplified gene fragments coding for 16S rRNA[J]. Appl Environ Microbiol, 63: 3367-3373.
Pearson K, 1926. On the coefficient of radical likeness[J]. Biometrika, 18: 105-117.

Phillips C J, Harris D, Dollhopf S L et al., 2000. Effects of agronomic treatments on structure and function of ammonia-oxidizing communities[J]. Appl Environ Microbiol, 66: 5410-5418.

Rozen Y, Belkin S, 2001. Survival of enteric bacteria in seawater[J]. FEMS Microbiol Rev, 25: 513-529.

Schramm A, Beer D, Wagner M et al., 1998. Identification and activity in situ of Nitrosospira and Nitrospira spp. as dominant populations in a nitrifying fluidized bed reactor[J]. Appl Environ Microbiol, 64: 3480-3485.

Seviour E M, Williams C J, Seviour R J et al., 1990. A survey of filamentous bacterial populations from foaming activated sludge plants in the eastern states of Australia[J]. Water Res, 24: 493-498.

Sokal R R, Michener C D, 1958. A statistical method for evaluating systematic relationships[J]. Kans Univ Sci Bull, 38: 1409-1438.

Suzuki M, Giovannoni S, 1996. Bias caused by template annealing in the amplification of mixtures of $16 \mathrm{~S}$ rRNA genes by PCR[J]. Appl Environ Microbiol, 62: 625-630.

Wagner M, Amann R, Lemmer H et al., 1993. Probing activated sludge with oligonucleotides specific for proteobacteria: inadequacy of culture-dependent methods for describing microbial community structure[J]. Appl Environ Microbiol, 59: 1520-1525.

Wagner M, Erhart R, Manz W et al., 1994. Development of an rRNA-targeted oligonucleotide probe specific for the genus Acinetobacter and its application for in situ monitoring in activated sludge[J]. Appl Environ Microbiol, 60: 792-800.

Wagner M, Loy A, 2002. Bacterial community composition and function in sewage treatment systems[J]. Curr Opin Biotechnol, 13: 218-227.

Wilderer P A, Bungartz $\mathrm{H} \mathrm{J}$, Lemmer $\mathrm{H}$ et al., 2002. Modern scientific methods and their potential in wastewater science and technology[J]. Water Res, 36: 370-393. 